\title{
Devido Processo Legal e Investigação Criminal
}

Daniel Fábio Fantini

Departamento de Polícicia Federal - Brasil

$$
\approx
$$

\section{RESUMO}

O presente trabalho discorre sobre a evolução do princípio do devido processo legal, nas suas duas dimensões - procedimental e substantiva, até ser expressamente consagrado na Constituição da República Federativa do Brasil de 1988. Explicita, portanto, que a cláusula do due process of law constitui baluarte de justiça, voltado à proteção dos direitos e garantias fundamentais do indivíduo, mormente a vida, a liberdade e a propriedade, contra toda e qualquer ação indevida do Estado. Lado outro, trata da investigação criminal enquanto procedimento de elucidação de fatos criminosos, à disposição do Estado, esclarecendo a relação entre a busca pela verdade fática com as imposiçôes obrigatórias do regime jurídico a que está submetida. Assim, considera que o conteúdo da investigação criminal e a sua forma são influenciados por disposições jurídicas, embora a busca pela verdade fática se aproxime das investigações científicas. Destarte, tendo em vista que a investigação criminal pode impor restrições, direta ou indiretamente, à vida, liberdade e propriedade dos indivíduos, justifica-se a aplicação do princípio do devido processo legal aos atos praticados no bojo de procedimento instaurado com o fim de apurar a prática de um delito. Por fim, identifica que os limites jurídicos impostos à investigação criminal se traduzem na efetiva aplicação do devido processo legal, seja nos aspectos inerentes ao conteúdo da investigação ou apenas em suas formalidades.

Palavras-Chave: Devido Processo Legal. Dimensões do Devido Processo Legal. Investigação Criminal. Contéudo e Procedimento. Restrições Legais à Investigação Criminal.

\section{INTRODUÇÃo}

Um dos princípios expressamente consagrados na Constituição da República de 1988 como baluarte na contenção e balizamento do uso dos poderes do Estado trata-se da obediência ao "devido processo legal". Oriunda do direito inglês e norte-americano, a garantia constitucional do devido processo legal impõe restrições ao Estado, evitando as ingerências indevidas 
na vida, liberdade e propriedade dos indivíduos. As restrições não são apenas de cunho procedimental, mas também possuem limitações substantivas, essencialmente de conteúdo.

Como se verá, o devido processo legal não é uma mera garantia procedimental relativa ao seguimento de rito processual, mas exige um agir justo do Estado, com espectro muito mais amplo, tanto no que diz respeito à observância de ritos, como também no que tange à obediência a normas de conteúdo.

Da mesma forma, a investigação criminal também possui dois aspectos fundamentais, quais sejam: conteúdo e forma, isto é, o saber e a expressão deste saber por um procedimento.

Assim, a investigação criminal se caracteriza pela realização de ator visando a elucidação do fato criminoso, ou seja, uma busca pela verdade, tal como qualquer investigação científica, mas conformada por limitações jurídicas de forma e contéudo. Neste aspecto, denota certa correlação ao princípio do devido processo legal em sua concepção ampla, que também possui duas dimensões: procedimental e substantiva.

Por outro lado, considerando que a investigação criminal pode repercutir sobre a vida, a liberdade ou a propriedade dos indivíduos, sendo um procedimento conduzido pelo Estado, evidentemente que este deverá respeitar o limite do devido processo legal, consubstanciado nos ditames legais que limitam a própria investigação.

Destarte, a investigação criminal deve primar pela busca à verdade por meio de sua forma própria, sem ofender aos direitos e garantias individuais, sejam eles de natureza procedimental ou substantiva.

\section{Do Devido Processo Legal}

A Constituição da República Federativa do Brasil de 1988 consagrou expressamente a garantia do devido processo legal:

Art. $5^{\circ}$

(...)

LVI - ninguém será privado da liberdade ou de seus bens sem o devido processo legal. 
Conforme SILVEIRA (2001), embora a origem da cláusula due process of law remonte a Magna Carta inglesa de 1215, ela somente foi positivada no direito brasileiro, pela primeira vez, no texto constitucional de 1988.

Cumpre, portanto, a tarefa hercúlea de resumir quase oitocentos anos de evolução história do instituto do devido processo legal para que se tenha a exata magnitude da garantia fundamental inscrita em nossa Constituição.

Como dito alhures, a origem da cláusula due process of law encontrase na Magna Carta de 1215. Contudo, a expressão due process of law somente foi positivada em 1354, quando o Parlamento inglês editou lei usando esse termo vindo a substituir a expressão law of the land, encontrada na Magna Carta, originalmente no vernáculo latino per legem terrae (CASTRO, 2006). Conforme inúmeras decisões da Suprema Corte norte-americana, as significações são sinônimas e denotam a amplitude do conceito do devido processo legal (Idem, Ibidem).

Em que pese às particularidades que envolvem a evolução do devido processo legal, é certo que a sua existência sempre foi marcada pela necessidade de impor limites à atuação do Estado quando estão em disputa os direitos fundamentais do indivíduo, como a vida, a liberdade e a propriedade.

No direito inglês, o devido processo legal foi incluído nas exigências feitas pelos barões feudais para refrear as intervenções do Rei João SemTerra, especialmente a cobrança de elevados tributos e outras imposições tirânicas (SILVEIRA, 2001). Posteriormente, a cláusula foi estendida a todas as pessoas do reino (Idem, Ibidem), uma vez que a Magna Carta "passou a ser reverenciada como fonte de vasto conglomerado de direitos e liberdades antigas, os quais foram considerados como o nascimento do direito do povo inglês" (Idem, Ibidem, p. 17).

Posteriormente, a proteção oferecida pelo princípio do devido processo legal à vida, liberdade e propriedade, valores considerados pelos ingleses como direito natural, foi transposta para as colônias norte-americanas (CASTRO, 2006). Assim, os princípios fundamentais do commom law inglês foram incorporados às colônias norte-americanas como denotam as suas Constituições, e dentre tais prescrições inseriu-se a cláusula due process of law (SILVEIRA, 2001). Mas somente na formação e independência dos 
Estados Unidos da América foram estabelecidas as condições ideais para o pleno desenvolvimento do princípio do devido processo legal, em todos os seus sentidos.

Primeiramente, antes mesmodo términoda Guerrada Independência, as colônias editaram constituiçóes prestigiando a cláusula due process of law, sob a expressão law of the land (PEREIRA, 2008), na tentativa de aproximar o seu conteúdo ao sistema jurídico da commom law, bem como firmar a compreensão sobre a existência de direitos fundamentais superiores.

Após a independência das treze colônias, a necessidade premente de constituir um Estado, fez surgir a Constituição norte-americana de 1787. Embora incialmente não contivesse uma declaração de direitos fundamentais, dez emendas foram acrescidas em 1791, constituindo o Bill of Rigths, dentre os quais se destaca a Emenda n. ${ }^{\circ}$ 5, na qual se previu, expressamente, o due process of law:

\section{Amendment $V$}

No person shall be held to answer for a capital, or otherwise infamous crime, unless on a presentment or indictment of a grand juri, except in cases arising in the land or naval forces, or in the militia, when in actual service in time of war or public danger; nor shall any person be subject for the same offense to be twice put in jeopardy of life or limb; nor shall be compelled in any criminal case to be a witness against himself, nor be deprived of life, liberty, or property, without due process of law; nor shall private property be taken for public use, without just compensation. ${ }^{1}$

A Constituição norte-americana inaugurou, destacamente, um Estado federativo, em que se previu a repartição de poderes entre a União (poder central) e os Estados-membros (poderes periféricos) (SILVEIRA, 2001), bem como a separação dos poderes políticos entre Legislativo, Executivo e um forte e independente poder Judiciário, que poderia anular leis promulgadas pelo poder Legislativo ou atos editados pelo poder Executivo (Idem).

1 Disponível em: http://www.archives.gov/exhibits/charters/bill_of_rights_transcript.html Acesso em: 19 set. 2010. "Ninguém será detido para responder por crime capital, ou outro crime infamante, salvo por denúncia ou acusação perante um Grande Júri, exceto em casos que se apresentem nas forças terrestres e navais, ou na milícia, quando chamadas a serviço ativo em tempo de guerra ou perigo público; ninguém poderá ser acusado duas vezes pelo mesmo crime com risco de perder a vida ou saúde; nem ser obrigado em qualquer processo criminal a servir de testemunha contra si mesmo; nem ser privado da vida, liberdade, ou bens, sem o devido processo legal; nem a propriedade privada poderá ser expropriada para uso público, sem justa indenização. (Tradução nossa) 
Estariam postos, portanto, nos dizeres de PEREIRA (2008, p. 113), os "pilares doutrinário-constitucionais" para o desenvolvimento do devido processo legal, quais sejam: "(a) constituição formal, rígida e suprema; (b) a efetiva vontade de fazer valer os direitos fundamentais e proteger os indivíduos perante o Estado (controle dos poderes instituídos), e (c) a supremacia judicial.

A preocupação, portanto, da nação que emergia, era garantir, definitivamente, sua independência e se prevenir contra as possíveis arbitrariedades do novo governo estabelecido em uma federação de estados-membros.

Assim, o direito natural invocado desde a transposição do commom law inglês para as colônias, foi reduzido a um texto escrito, rígido, cuja alteração dependia de condições excepcionais, de um rito especial.

No que tange ao controle dos poderes instituídos, a Constituição dos Estados Unidos criou organização estatal fortemente marcada pela idéia da completa separação de poderes, considerando o pensamento iluminista, mormente Montesquieu, de que a concentração de poderes é a origem da opressão dos governantes sobre os governados. Neste contexto, o Poder Judiciário deixa de ser mero coadjuvante, para adquirir status e atribuições capazes de contrabalançar os demais.

Além disso, o preconceito norte-americano contra o Poder Legislativo, advindo de sua identificação ao Parlamento inglês - símbolo maior da metrópole dominante (CASTRO, 2006), resultou no deslocamento da proteção dos direitos e garantias fundamentais inscritos na constituição rígida para o Poder Judiciário.

Por fim, a própria separação de poderes em duas esferas, central e estadual, prevista na constituição, exigia um guardião, o mesmo Poder Judiciário, para garantir a existência do próprio Estado, quando presentes os constantes conflitos oriundos desta separação (PEREIRA, 2008), sob pena de, por um lado, desagregá-lo; e pelo outro, de sufocar os estados-membros independentes.

A própria Guerra Civil, travada no século seguinte, é exemplo evidente do embate entre estas duas esferas de poder (central e estadual), gerando outras emendas constitucionais, quando do seu término, com especial destaque à Emenda n..$^{\circ}$ 14, que estabeleceu a aplicação do devido processo legal a qualquer cidadão norte-americano, independentemente das leis estaduais existentes, ampliando sua proteção para além da esfera central, obrigando a todos os estados-membros a observarem o seu conteúdo: 


\section{AMENDMENT XIV}

Section 1.

All persons born or naturalized in the United States, and subject to the jurisdiction thereof, are citizens of the United States and of the State wherein they reside. No State shall make or enforce any law which shall abridge the privileges or immunities of citizens of the United States; nor shall any State deprive any person of life, liberty, or property, without due process of law; nor deny to any person within its jurisdiction the equal protection of the laws. ${ }^{2}$

Estabelecida, em apertadíssima síntese, a base temporal na qual o devido processo legal surgiu e se desenvolveu, cumpre tratar de seu conteúdo, também amoldado por esta evolução histórica, cujos contornos serão tratados nas próximas seções deste capítulo, pois cuidam de aclarar os sentidos dados à cláusula due process of law com o passar dos anos.

Considerando, portanto, que o princípio do devido processo legal apresentou conteúdo variável ao longo dos tempos (LUCON, 2001), se percebe a dificuldade em conceituá-lo, nos dizeres de SILVEIRA, 2001, p. 236:

O princípio do devido processo legal incorpora valores culturais amplos e profundos sentimentos de justiça sedimentados por séculos na cultura do povo anglo-saxão, inclusive em sua progenie americana. Diante da amplitude do conceito, não pode ser definido e dissecado tecnicamente, mas se manifesta e interpenetra no direito, e é sentido naturalmente pelo homem comum e de bom senso, em virtude da carga de evidência que carrega em si mesmo.

De qualquer forma, Thomas Cooley, (Apud MACIEL, 2009, p. 6-7), tenta nos oferecer uma noção abrangente do princípio:

O termo devido processo legal é usado para explicar e expandir os termos vida, liberdade e propriedade epara proteger a liberdade e a propriedade contra legislação opressiva ou não-razoável, para garantir ao individuo o direito de fazer de seus pertences o que berm entender, desde que seu uso e ações não sejam lesivos aos outros como um todo.

2 Disponível em: http://www.archives.gov/exhibits/charters/constitution_amendments_11-27.html Acesso em 19 set. 2010. “Todas as pessoas nascidas ou naturalizadas nos Estados Unidos, e sujeitas a sua jurisdição, são cidadãos dos Estados Unidos e do Estado onde residem. Nenhum Estado poderá fazer ou executar leis restringindo os privilégios ou as imunidades dos cidadãos dos Estados Unidos; nem poderá privar qualquer pessoa de sua vida, liberdade, ou propriedade sem o devido processo legal, ou negar a qualquer pessoa sob sua jurisdição a igual proteção das leis" (Tradução nossa) 
Então, trataremos nas próximas seções de suas duas dimensões: procedimental e substantiva, com o intuito de esclarecer o conteúdo do devido processo legal.

\subsection{Dimensão Procedimental do Devido Processo Legal}

Inicialmente, o princípio do devido processo legal era compreendido apenas como uma garantia de direito processual penal, que asseguraria um rito regular do processo a ser observado pelas cortes judiciárias.

Dentro deste sentido restrito, o devido processo legal fundamentava uma série de garantias expressas e implícitas do sistema processual penal, dentre as quais se destacavam, no Bill of Rights, expressamente, conforme CASTRO (2006, p. 29-30):

a proibição de edição de "bill of attainder" e de Leis retroativas (ex post facto Law), ambas tratadas no art. $1^{\circ}$, Seção 9, item 3, bem como as disposiçôes contidas na $5^{a}$ Emenda, como seja, o direito a julgamento por júri (juri trial), a proibição de alguém ser julgado duas vezes pelo mesmo fato (double jeorpardy) e a vedação da auto-incriminação forçada(self incrimination). Ajunte-se, ainda, as garantias ditadas pela $6^{a}$ Emenda, a saber, o direito a um julgamento rápido e público (speedy and public trial), por juri imparcial e com competência territorial predeterminada, bem como o direito de ser informado acerca da natureza e causa da acusação (fair notice), além do direito de defesa e ao contraditório...como de resto o direito à assistência de advogado.

Destaca-se ainda, implicitamente, o direito de estar presente perante o juízo (his day in the Court) e de ser ouvido em audiência judicial (prompt hearings); "o direito de qualquer suspeito de infração criminal ser notificado pela autoridade policial da sua prerrogativa de permanecer calado" (grifos nossos) (CASTRO, 2006, p. 31); e de ser assistido por um advogado, ainda que não tivesse condições financeiras de contratar um.

Enfim, o devido processo legal procedimental propugna o direito do réu de conhecer as acusaçóes que pesavam sobre ele e "de ser ouvido no tempo oportuno e da maneira adequada" (SILVEIRA, 2001, p. 304) perante o juízo imparcial antes que seja formulado um provimento definitivo. $\mathrm{O}$ devido processo legal exige um processo, nos dizeres de Daniel Webster (Apud 
CASTRO, 2006, p. 32), "which hears before it condemns, which proceeds on inquiry and renders judgment only after trial."

Assim, a cláusula do procedural due process compreende, em si, as previsões: 1) do contraditório e da ampla defesa, uma vez que o acusado deve conhecer das imputaçôes que lhe são feitas e tem o direito de contestálas, inclusive produzindo provas sob a orientação de defesa técnica; 2) da presunção de inocência, incluída a máxima do in dubio pro reo; 3) das condições para a imposição da prisão, mormente a de caráter processual ou cautelar, e por fim; 4) da vedação da utilização de provas obtidas de forma ilícita.

Em linhas resumidas, a aplicação do devido processo procedimental, no âmbito do direito processual penal norte-americano, se estabeleceu nos princípios supracitados e embora tenham a aparência de determinar limites rígidos para atuação do Estado, o seu conteúdo permanece elástico, cujos contornos serão estabelecidos após a análise particular de cada caso, tendo em vista o contexto histórico, social e legal da época.

SILVEIRA (2001) cita o caso Mappv. Ohio - 1961, em que a Suprema Corte dos Estados Unidos da América, sob forte interesse de assegurar os direitos fundamentais, aplicou o princípio da exclusão das provas ilícitas, ampliando o seu sentido, para considerar irregulares as provas encontradas após a realização de busca e apreensão ocorrida sem um mandado judicial e sem uma causa provável - probable cause, mesmo tendo ciência de que elas demonstravam cabalmente o cometimento do crime. Posteriormente, restringindo a aplicação da exclusão das provas ilícitas, a Suprema Corte (California v. Ciraolo - 1986) considerou que o sobrevôo a uma residência, sem causa provável ou autorização judicial, por meio do qual se identificou uma plantação de maconha, não ofende ao devido processo legal (Idem, Ibidem). Da mesma forma, admitiu em US v. Leon - 1984 provas colhidas em cumprimento regular de mandado de busca e apreensão, mas cujo objeto foi ampliado pela polícia por boa fé - good faith (Idem, Ibidem).

Vê-se, portanto, que o devido processo legal procedimental não se resume ao direito público subjetivo ao processo regular, mas trata-se, também, de garantia procedimental que pautará as condutas durante todo o desenrolar da disputa em juízo. 
De qualquer forma, as implicações do procedural due process oriundas do direito processual penal repercutiram na esfera cível. Neste aspecto, a adequação entre o ius libertatis e o ius puniendi denotou o caráter público do processo, em que o Estado deve garantir a regularidade no direito de tutela jurisdicional, como forma de respeitar e implementar a própria Justiça.

Considerandotaisargumentos, odevido processolegal procedimental passou a garantir, no âmbito do processo civil, o direito à tutela jurisdicional e o princípio da ampla defesa e do contraditório, ainda que a disputa tenha por objeto o interesse exclusivamente privado das partes envolvidas, já que se entendia, nesta ocasião que o desenvolvimento do processo ocorre em uma esfera pública que deve ser levada a efeito pelo próprio Estado.

Decorre daí, portanto; 1) "a inafastabilidade da cognição judicial" (CASTRO, 2006, p. 302), pois o Poder Judiciário não poderá ser excluído da apreciação de qualquer ameaça ou lesão a direito; 2) o contraditório e a ampla defesa; 3) o juízo natural, que determina, de antemão, qual órgão competente para apreciar a lide; 4) o seguimento dos ritos processuais; 5) a restrição do provimento judicial à demanda proposta, e; 6) a fundamentação das decisões.

Por outro lado, além da ampliação da aplicação do devido processo legal ao processo civil, a garantia constitucional também lançou proteção contra as ingerências indevidas contidas em procedimentos administrativos. Neste diapasão, o devido processo legal procedimental procurou conter os abusos especialmente praticados pelas autoridades administrativas quando se utilizam dos poderes de polícia, de disciplina, de regulamentação ou de revisão dos atos administrativos que estão à disposição da Administração Pública para o cumprimento de seus deveres.

Nos moldes da guarida conferida aos âmbitos processuais penais e cíveis, acima mencionadas, a Administração Pública também é obrigada a respeitar a ampla defesa e o contraditório em procedimento administrativo aos cidadãos que tiverem a sua vida, liberdade ou propriedade possivelmente atingidos pela edição de ato que implique em punição administrativa (CASTRO, 2006). Da mesma forma observada na proteção conferida penal e civilmente, os atos deverão ser motivados e fundamentados, e o rito previsto deverá ser cumprido, conforme preconizado em lei. 
Contudo, as restrições impostas ao Estado pelo devido processo legal não se resumiram à justeza do procedimento penal, cível ou administrativo. Durante a sua evolução histórica, o sentido do due process of law foi estendido para verificar, inclusive, a adequação do conteúdo dos atos do poder público, inclusive da própria lei, com o sistema jurídico. Esta dimensão substantiva do devido processo legal será tratada na próxima seção.

\subsection{Dimensão Substantiva do Devido Processo Legal}

A dimensão substantiva do devido processo legal não trilhou a mesma linha de evolução da dimensão procedimental do princípio, nem mesmo onde foi desenvolvida e aplicada.

A idéia surgiu ainda na Inglaterra por conta das manifestações do juiz Sir Edward Coke, que "sustentava a existência de uma força de contenção substantiva na histórica cláusula de garantia dos direitos individuais" (PEREIRA, 2008, p. 144) para impedir que atos do poder público, mormente as leis, avançassem sobre a propriedade, liberdade e a vida dos cidadãos, sem um motivo plausível. Contudo, as idéias de Coke, consistentes na nulidade das leis que atentassem contra a razão ou contra o direito comum vão evoluir nos Estados Unidos da América, especialmente em função da judicial review, implantada pela contribuição do Justice John Marshall no famoso caso Marbury v. Madison - 1803 que instituiu o controle de constitucionalidade das leis pelo Poder Judiciário (SILVEIRA, 2001).

Neste país, a dimensão substantiva do devido processo legal foi invocada inicialmente para resguardar o direito de propriedade. O caso, infelizmente, marcou negativamente a Suprema Corte, posto que serviu para manter a propriedade em detrimento da abolição da escravatura em alguns estados do sul do país, conforme se depreende do terrivelmente famoso case Dred Scott $v$. Sandfor - 1857. Assim, com base no substantive due process, a Suprema Corte considerou arbitrária uma lei que abolira a escravidão editada por um estadomembro, porque ela interferia no direito de propriedade de possuir um escravo (SILVEIRA, 2001). As conseqüências de tal decisão, "catapultou - ou mais suavemente, colaborou para - o ingresso do país na guerra civil" (Idem, Ibidem, p. 419). Alguns anos depois, a teoria foi resgatada do péssimo episódio e, segundo o Justice John Harlan, (apud MACIEL, 2009, p. 10), a força substantiva do princípio do devido processo legal tornou a ser necessária para a proteção da vida, liberdade e propriedade contra leis arbitrárias: 
Assim, as garantias do devido processo, embora tendo suas raizes no per legem terrae da Magna Carta e considerada como salvaguardas processuais contra a usurpação e tirania do executivo, também se transformaram neste pais numa (verdadeira) barreira contra a legislação arbitrária.

A doutrina do devido processo substantivo ampliou a força do Poder Judiciário, pois além do judicial review, por meio do qual os juízes já faziam uma análise de adequação de leis e atos administrativos com os demais princípios e normas constitucionais, agora também poderiam se imiscuir no mérito destas leis e atos, tal como um poder político, para dizer se, substancialmente, eles apresentavam pressupostos de "justiça, necessidade e razoabilidade" (SILVEIRA, 2001, p. 422) para regrar a vida, a liberdade ou a propriedade dos cidadãos.

Como dito, o devido processo substantivo se preocupou, principalmente, contra a intervenção arbitrária no direito de propriedade, sendo que nos diversos julgados em que foi invocado ou rechaçado, foram privilegiadas as idéias de liberdade contratual ou de intervenção governamental, conforme o contexto histórico, social e econômico. Mas aos poucos, também avançou para garantir a vida e a liberdade.

Assim, em Lochner v. New York - 1905 (Idem, Ibidem), a decisão da Suprema Corte prestigiou a liberdade contratual, em detrimento da "legislação regulamentar intervencionista” (PEREIRA, 2008, p. 140), considerada arbitrária, sinônimo de "ação não razoável” (SILVEIRA, 2001, p. 428).

Posteriormente, em virtude da crise econômica de 1929 e da necessária intervenção estatal na economia, a Suprema Corte norte-americana decidiu rever o precedente Lochner, criando a utilização de dois padrões de escrutínio, também chamado "duplo-padrão" (PEREIRA, 2008, p. 141) na análise da conformidade da lei. Esta fórmula propugnava que se a lei regulamentasse aspectos da área econômica, ela deveria ser analisada sob o critério da razoabilidade, considerando, portanto, as decisões legislativas que a promulgaram. Noutro giro, se a lei afrontasse direitos e liberdades civis era “presumidamente considerada suspeita” (SILVEIRA, 2001, p. 440).

Este arrefecimento da dimensão substantiva do devido processo legal propiciou novas incursões indevidas na esfera dos direitos fundamentais, como se verificou no case Korematsu v. United States - 1944, (Idem, Ibidem) 
no qual um americano foi condenado por se recusar a obedecer à determinação de seguir para um campo de concentração durante o período da 2a Guerra pelo simples fato de ter ascendência japonesa. No caso, apesar da condenação ter sido mantida, o voto do Justice Black acrescentou mais um elemento na evolução da dimensão substantiva do devido processo legal, ao afirmar que as leis elaboradas para restringir direitos civis baseadas em critérios de raça devem se sujeitar "ao mais rígido escrutínio" (Idem, Ibidem, p. 463) pelo Poder Judiciário. Assim, além de suspeita, a lei que se propor a regulamentar ou restringir os direitos fundamentais de determinados grupos de pessoas deverá ser objeto de escrutínio estrito, de análise acurada pelo Poder Judiciário, de forma que o Estado deverá comprovar, imperiosamente, a necessidade de tais medidas. Assim, no período pós-II Guerra, especialmente nas décadas de 1950 e 1960, a efetiva defesa dos direitos fundamentais pelo substantivo processo legal ganhou força novamente, como demonstra a decisão tomada pela Suprema Corte em Brown v. Board os Education of Topeka - Kansas - 1954 (Idem, Ibidem), julgando atentatória a legislação estadual que segregava negros e brancos. No caso, embora o fundamento fosse a igualdade de tratamento, considerou-se que a legislação estadual segregadora não suportou o escrutínio estrito, posto que o Estado não comprovou a imperiosidade de manter o segregamento.

Ainda nos dias atuais, o devido processo substantivo está sendo aplicado para ampliar o sentido dos termos liberdade e vida, de forma a integrar e regulamentar as legislações que versam sobre privacidade, aborto, homossexualismo, eutanásia. No caso, a cláusula está protegendo direitos implícitos. Assim, a Suprema Corte utiliza os padrões de escrutínio, sob a orientação do devido processo substantivo, para analisar se as leis editadas interferem de forma irrazoável ou proibida sobre a esfera de direitos fundamentais da pessoa humana, mormente a liberdade e a vida. Cite-se, por exemplo, casos em que leis estaduais foram invalidadas porque proibiam "a distribuição de anticonceptivos a solteiros"3 (PEREIRA, 2008, p. 220) ou criminalizavam o homossexualismo ${ }^{4}$ (PEREIRA, 2008).

\section{I.3 CONSIDERAÇÕES FINAIS DO CAPÍTULO}

A evolução da clausula due process of law, em suas duas dimensões, prestou relevantes serviços para promover a atualização e a transformação

3 Cf. Eisenstadt v. Baird, 405 U.S. 438 (1972)

4 Cf. Lawrence $v$. Texas, 539 U.S. (2003) 
do direito constitucional norte-americano, proporcionando as mais diversas leituras de um texto que perdura para além dos seus duzentos anos, se tornando, verdadeiramente, num importante instrumento de limitação dos poderes do Estado, com significado muito maior do que uma simples garantia processual.

Cumpre transcrever as palavras de José Alfredo Baracho (1982, p. 90):

As expressôes 'law of the land' e 'due process of law' examinadas conjuntamente, na Inglaterra e nos Estados Unidos, deram origemà construção jurisprudencial, com o objetivo de proteção aos direitos do indivíduo, em especial em matéria de garantias processuais. Com o tempo, a cláusula do due process of law passou a ter maior relevo, alargando-se no âmbito da doutrina. De uma garantia, em face do juizo, passa a assegurar igualdade de tratamento frente a qualquer autoridade. Esta ampliação de sentido propiciou a limitação constitucional dos poderes do Estado: 'O instrumento está criado.' Como escreve Pound, o 'due process of law' é um 'standard', pelo qual se guiam os tribunais, e, assim sendo, deve aplicar-se tendo em vista circunstâncias especiais de tempo e de opinião pública em relação ao lugar em que o ato tem eficácia.

Embora o princípio esteja expressamente consagrado no direito pátrio há pouco tempo e não carregue toda força histórica da evolução conceitual tratada acima, sua importância é indiscutível, nos dizeres do Ministro Adhemar Maciel (2009, p. 1): "é rara uma sessão do STJ em que não se fale no 'devido processo legal'. Isso, por si só, já denuncia sua importância."

De qualquer modo, a sua positivação no texto constitucional pátrio o torna norma de eficácia jurídica absoluta, embora a evolução de sua aplicação dependa da própria sedimentação do Estado Democrático de Direito (DAURA, 2009).

No último capítulo deste artigo, se pretende ampliar os horizontes teóricos da força limitadora do devido processo legal para a investigação criminal. Mas, antes, incumbe tratar da investigação criminal.

\section{Da Investigação Criminal}

Inicialmente cumpre partir de um conceito de investigação criminal. Tal conceito, com pequenas variações, é quase unanimemente repetido pelos estudiosos, como abaixo transcrito: 
A investigação criminal é processo de procura de indícios e vestígios que indiquem e expliquem e que façam compreender quem, como, quando, onde e porquê foi cometido o crime X. (VALENTE, 2009, p. 309).

Destarte, percebida a ocorrência de um fato supostamente tipificado como crime, é executada uma série de atos, dentro de um método legal, visando a sua possível reconstrução.

Note-se que deste conceito usualmente difundido, podemos dissecar a investigação criminal em duas realidades indissociáveis: uma fática; e outra relativa aos conceitos jurídicos que definem o que é crime, as suas circunstâncias e conseqüências, bem como ao processo que estabelece o método de desenvolvimento da investigação, todos estes relacionados à ciência do direito.

Contudo, se todos os elementos acima citados integram o conteúdo da investigação criminal, confluindo para elaboração de uma "verdade processual”, conforme expôs FERRAJOLI (2006, p. 36, ss), por certo que existe também "um método legal de demonstração obrigatório" (PEREIRA, 2010, p. 218), uma formalização ou instrumento que exprima o conhecimento atingido e que possibilite a verificação do conhecimento elaborado (Idem, Ibidem).

\section{I DO CONTEÚDO DA INVESTIGAÇÃO CRIMINAL}

O conteúdo da investigação criminal congrega, portanto, uma pesquisa científica do fato, orientada por conceitos jurídicos que servem de parâmetro para o direcionamento, aprofundamento e limite metodológico desta pesquisa.

Trata-se, realmente, de uma pesquisa judiciária da verdade (FOUCAULT, 2001). A necessidade de conciliar a verdade fática com as verdades jurídicas, de forma harmoniosa, resume a enorme dificuldade de compreensão e da evolução da investigação criminal, quiçá do próprio direito penal e processual penal.

Segundo FERRAJOLI (2006, p. 36), "Se uma justiça penal integralmente "com verdade" constitui uma utopia, uma justiça penal completamente "sem verdade" equivale a sistema de arbitrariedade". 
Na história ocidental, se registrou algumas formas jurídicas de apontar certa "verdade", valendo-se de critérios diversos dos utilizados atualmente, tais como: 1) a prova da importância social de um indivíduo - nada dizia a respeito do fato, mas era suficiente para influenciar a responsabilização deste indivíduo conforme a sua posição social; 2 ) as provas verbais, consistentes na repetição de dizeres ou fórmulas que podiam decidir o processo conforme a sua adequação à forma considerada correta; 3 ) as provas mágico-religiosas do juramento, nas quais o acusado deveria prestar juramento, sem hesitação ou recusa, perante um ser supremo, sobre a sua inocência; 4) as provas corporais, físicas, chamadas ordálios, nas quais o acusado se submetia a uma espécie de provação corporal para se garantir vencedor do processo, como por exemplo, se lograsse andar sobre brasas sem demonstrar cicatrizes, vencia o processo (FOUCAULT, 2001).

Nas hipóteses citadas, denota-se que os critérios utilizados se baseavam, quase exclusivamente, em regras jurídicas, abstraídos de qualquer empirismo fático. A rigor, não se tratava da análise do fato, conforme a sua realidade, mas apenas de uma ritualística jurídica.

Séculos de evolução histórica e do próprio direito, se conquistou, primeiramente, conforme Foucault (2001), uma forma racional da prova e sua demonstração, que implicam em um modo de produção da verdade.

Neste contexto, o estabelecimento de uma verdade fática tornou-se base fundamental para qualquer decisão jurídica de cunho penal.

E incumbirá à investigação criminal a reconstrução do fato, da mesma forma observada em outras espécies de investigações científicas, posto que se utilizam de padrões de averiguação semelhantes (DUTRA, 2010).

A aproximação da investigação criminal com a investigação científica, conforme Pereira (2010), no que tange à definição da verdade fática, também pode ser percebida pela possibilidade de transposição de conceitos típicos do discurso científico para o conteúdo da investigação criminal, como, por exemplo, o estabelecimento do problema (um corpo encontrado morto, abandonado em local ermo), das hipóteses (alguém, utilizando-se de uma arma de fogo, matou e escondeu o cadáver) e das bases de dados (hábitos da vítima, cultura local, histórico de violência, causa da morte, etc.). Resguardase, evidentemente, as suas particularidades fundamentais, mormente o objeto (crime) e o método, ambos fornecidos pela ciência do Direito. 
Embora alguns autores reduzam o objeto da investigação criminal a um fato (criminoso) histórico, passado (Idem, Ibidem), impossível de experimentação, mas sujeito apenas de comprovação, (FERRAJOLI, 2006) as modernas técnicas de investigação, tais como a interceptação de comunicação de voz e dados, a infiltração de agente, a videovigilância, dentre outros, indicam a necessidade de estudo aprofundado sobre o tema, posto que nestes casos, a investigação criminal acontece contemporanemante à ocorrência do crime, de forma concomitante, consistindo, propriamente, no seu registro em tempo real, e não na reconstrução do fato.

Assim, entendido que o objeto da investigação criminal é o fato considerado criminoso, cumpre ressaltar que, conforme o princípio da estrita legalidade, somente o direito pode definir quais destes fatos adquirem a adjetivação de delituoso, do ponto de vista jurídico-penal a merecer as reprimendas do sistema punitivo legal. Além da definição do fato, as circunstâncias relevantes para a investigação criminal também serão apontadas pela própria lei, como qualificadoras ou formas privilegiadas, condições de agravamento ou atenuantes. De qualquer forma, a adequação do fato à norma, chamado subsunção, também se submete à possibilidade de verificação, mas esta de cunho classificatório (FERRAJOLI, 2006), como por exemplo, o fato X (por exemplo, corpo encontrado morto por causas externas) é um homicídio e não um suicídio, destacando-se:

uma justiça penal não arbitrária deve ser em certa medida "com verdade", quer dizer, baseada sobre juizos penais predominantemente cognitivos (de fato) e recognitivos (de direito), sujeitos como tais a verificação empirica (FERRAJOLI, 2006, p. 29).

Ainda no contexto do conteúdo da investigação criminal, resta tratar do método de investigação.

O método da investigação criminal não é estabelecido formalmente pela lei, de modo a impor um rito de cumprimento obrigatório, embora haja previsões expressas e vedações implícitas sobre os limites jurídicos para a produção da prova. Sobre este balizamento, o devido processo legal exerce papel fundamental que será tratado nas próximas seções.

Conforme Pereira (2010, p. 219):

não se trata de um método em sentido positivo, (que se mantém a requerer uma sistematização empirica pelos órgãos de investigação), mas em sentido negativo (limitado juridicamente). 
É neste momento que a investigação criminal se afasta de forma mais intensa dos demais tipos de investigação. Neste particular, a validade das provas coletadas influencia a verdade produzida pela investigação.

Ou seja, as provas colhidas fora dos limites impostos pelo direito, portanto inválidas juridicamente, não podem ser utilizadas para determinar a verdade processual, razão pela qual nem sempre haverá correspondência entre a verdade fática e a verdade processual.

Nos dizeres de Ferrajoli:

não ésó a verdade que condiciona a validade, masétambém a validade que condiciona a verdade no processo. Estaé, com efeito, por assim dizer, uma verdade normativa, no tríplice sentido: a) uma vez comprovada definitivamente, tem valor normativo; b) estáconvalidadapornormas; c) é verdade na medida em que seja buscada e conseguida mediante o respeito às normas. (FERRAJOLI, 2006, p. 50)

Enfim, o conteúdo da investigação criminal é composto pela investigação científica do fato criminoso, especialmente a reconstrução histórica do acontecido, tendo por condicionantes às determinações jurídicas que se referem à definição do crime, sua tipificação, suas circunstâncias e conseqüências, valendo-se de um método legal negativo que não estabelece um rito necessário, mas determina limite, ditado pelo devido processo legal, à produção e validade das provas colhidas.

\subsection{DA FORMA DA INVESTIGAÇÃO CRIMINAL}

Evidentemente que o conteúdo da investigação criminal deve ser exteriorizado de alguma forma para que informe o conjunto das ações realizadas e os resultados obtidos, especialmente para que a investigação atinja as suas finalidades, mormente a reconstrução de um fato criminoso sob as orientações do sistema jurídico criminal.

Dentro da concepção de proximidade entre investigação criminal e as investigações científicas, Dutra (2010, p. 144-145) relaciona inúmeras "condições ambientais e objetivas" que seriam comuns a ambas, dentre as quais destaca, referindo-as às investigações científicas:

(a) um dialeto técnico, com vocabulário especifico, inclusive contendo termos para espécies (naturais ou sociais); 
(...)(b) meios materiais que comuniquem todos os elementos acima em uma literatura cientifica própria.

Dutra (Ibidem, p. 146-147) aponta que a investigação policial também se utiliza de elementos análogos:

(a) um dialeto técnico, com vocabulário especifico, que permite descrevernostermos da legislaçãovigente asformas de comportamento ilegal ou criminoso;

(...)(b) meios formais para comunicar os elementos acima às formas de instrução de processos no sentido amplo, isto é, não apenas a instrução formal de um processo judicial, mas a instrução do próprio processo de investigação que conduzirá àquele (grifos nossos)

No âmbito das investigações criminais, os meios formais para comunicar os elementos obtidos durante a apuração são definidos pelo direito, posto que as investigações criminais estão vinculadas, inexoravelmente, a um processo, seja ao judicial, seja ao seu próprio desenvolvimento, com fim de apontar responsabilidade criminal, caso exista.

Assim, nos dizeres de Valente (2009, p. 317):

A investigação criminal compõe-se de actos juridicamente préordenados quesãopraticadosporgrupos depessoas legalelegitimamente autorizadas, que seguem um modelo padronizado e sistemático, eque irão dizer se existiu ou não um crime, determinar os autores e reunir as provas necessárias a uma decisão(grifos nossos)

No Brasil, por excelência, o instrumento que dá forma à investigação criminal é o inquérito. $\mathrm{O}$ modelo de descoberta judiciária da verdade pelo instrumento racional do inquérito tem origem na Grécia Antiga (FOUCAULT, 2001), mas foi no Império Romano que o "Inquisitio" se constituiu, segundo Daura (2009, p. 66) como uma "fase persecutória penal de nítido caráter investigatório que, após esclarecidos os fatos segundo os critérios vigente naquela época, passava-se, de pronto, ao processo, cognitio".

Em nosso país, se atribuiu à Polícia Judiciária, a incumbência de realizar esta "atividade persecutória incial para desvendar a autoria e comprovar a materialidade dos ilícitos penais" (Idem, Ibidem, p. 67). Conforme o Prof. Daura (Idem, Ibidem), incialmente as atribuições de investigação criminal eram realizadas pelos representantes do próprio Poder Judiciário, mas com o passar do tempo, "com o aumento da população e das cidades, e consequentemente da criminalidade”, tais atividades foram delegadas à Polícia Judiciária. 
Destarte se sedimentou o principal instrumento de formalização da investigação criminal, no caso, o inquérito policial, cujo regramento está previsto no Código de Processo Penal, mormente no Título II, cuja nomeclatura lhe faz referência expressa.

Contudo, o inquérito policial não é o único instrumento que expressa o conteúdo da investigação criminal. No caso, o direito pátrio também faz menção ao inquérito policial militar, conforme o Título III do Código de Processo Penal Militar. Os instrumentos formais de investigação criminal acima citados (inquérito policial e inquérito policial militar) estão expressamente previstos em lei, compreendendo, inclusive, a descrição de um rito formal mínimo que versa sobre o início, o desenvolver e o término da investigação.

Contudo, existem outros normativos legais que atribuem expressamente a função investigatória a outras autoridades, embora sejam silentes quanto ao procedimento formal a ser aplicado. Citem-se: 1 ) as Comissões Parlamentares de Inquérito - CPIs, (art. $58, \$ 3^{\circ}$ da Constituição da República de 1988); 2) as Procuradorias Gerais de Justiça, que deverão apurar o envolvimento de membros do Ministério Público em eventual ilícito penal (Lei n. ${ }^{\circ}$ 8.625/93 - Lei Orgânica Nacional do Ministério Público); 3) os Tribunais de Justiça, Regionais Federais ou Superiores, que deverão promover a investigação criminal quando houver possível cometimento de ilícito penal por magistrado (Lei Complementar n. ${ }^{\circ}$ 35/79 - Lei Orgânica da Magistratura Nacional).

Há, ainda, outras duas hipóteses, cujas autoridades possuem função investigativa, mas estes poderes foram conferidos por regimento interno, sem previsão constitucional ou legal, quais sejam: 1) o Presidente ou Ministro do Tribunal deverá presidir inquérito ou delegar esta função a outra autoridade quando ocorrer um crime no interior da sede do respectivo Tribunal (art. 43 RISTF; art. 58 RISTJ) e; 2) as polícias do Senado Federal e da Câmara dos Deputados (Resolução nº. 59/2002 do Senado Federal e Resolução nº. 018/2003 da Câmara dos Deputados) também serão responsáveis por apurar ilícitos praticados no interior das casas legislativas. Estas duas hipóteses, como já afirmado, não possuem qualquer sustentação baseada na legalidade, e portanto, plenamente discutível a constitucionalidade de tais resoluções e dispositivos regimentais, uma vez distoantes da determinação contida no artigo 144 da Constituição Federal de 1988; 
Por fim, o Prof. Daura (2009, p. 86) contempla outra autoridade dotada de função investigatória, com previsão expressa no direito positivo, no caso:

aquela desenvolvida pelo procurador do Tribunal Penal Internacional, pois se submetendo o Brasil, em face de sua adesão, à jurisdição de Tribunal Penal Internacional, os crimes de genocidio, os crimes contra a humanidade, os crime de guerra e o crime de agressão (entre paises) podem ser investigados em nosso território por autoridade estrangeira em sede de inquérito, sendo que tal Tribunal visa à responsabilização de pessoas físicas.

Resumidamente foram descritas as autoridades expressamente auto$\underline{\text { rizadas, }}$ seja pela lei em sentido lato ou por regulamento, a presidirem uma investigação criminal, ressalvando-se, contudo, a falta de previsão legal sobre o procedimento formal a ser utilizado.

Dos exemplos citados, além dos inquéritos policiais (civil e militar), as Comissões Parlamentares de Inquérito - CPIs - possuem certo regramento dos trabalhos de investigação, previsto em regimento interno, que estabelece, minimamente, as hipóteses de instauração, desenvolvimento e conclusão da investigação. Além das CPIs, a Resolução n. ${ }^{o}$ 59/2002 do Senado Federal, que dispõe sobre o poder de polícia no Senado Federal, e o Regimento Interno da Câmara dos Deputados, também prevêm que serão observados, no inquérito (presidido pelas polícias legislativas), o Código de Processo Penal e os regulamentos policiais do Distrito Federal, no que lhe forem aplicáveis" (art. 4º $\$ 1^{\circ}$ da Resolução 59/2002 e art. 269 do RICD) quando estiverem investigando os ilícitos penais praticados no interior da sede do Poder Legislativo.

Percebe-se, portanto, a escassez procedimental do direito pátrio no que toca à investigação criminal, embora o instrumento formal de apresentação da investigação seja fundamental dentro de uma concepção de processo penal que respeite ao devido processo legal.

No próximo capítulo deste artigo, se pretende tratar da aplicação do devido processo legal no que tange ao conteúdo e forma da investigação criminal.

\section{O Devido Processo Legal e a Investigação Criminal}

Conforme a moderna doutrina constitucionalista, a Constituição deve ser entendida como a pedra fundamental da formação do Estado e da 
conformação de umasociedade.Deonde, por meio de princípios estruturantes, se obtém uma ordem essencial que regula todo o ordenamento jurídico, e dos quais também seinferem restrições elimites aolegislador ordinário e aos demais entes públicos na utilização de seus poderes quando possam atingir direitos e garantias fundamentais do indivíduo (CANOTILHO, 1998). Assim, os princípios e normas constitucionais emanam suas determinações para todos os demais regramentos ordinários, sejam eles materiais ou processuais exigindo a adequadação destes dispostivos, ainda que interpretativa, sob pena de serem excluídos da ordem jurídica.

Considerando a positivação do devido processo legal no texto constitucional brasileiro, é patente que o seu conceito e abrangência formam toda ordem jurídica nacional, e sua observância deve ser completa, por todo e qualquer ato praticado pelos entes estatais. Conforme Pereira (2008, p. 75):

\begin{abstract}
A claúsula representa uma diretriz fundamental, um balizamento estrito e inafastável, embora elástico, traçado para pautar qualquer ação ou disposição dos poderes instituidos, na direção do indivíduo - da sua vida, da sua liberdade e do seu patrimônio. Assim, não há ato estatal, de qualquer dos três poderes ou seus agentes, que possa contornar, fugir, evitar, deixar de lado ou ignorar o Due Process - o procedimento que faça Justiça - na sua inteireza: autorização em comando válido, cumprimento estrito do procedimento e concretização de um resultado qualificado como justo.
\end{abstract}

Como se viu, o princípio do devido processo legal não possui significado restrito ao seguimento de ritos processuais, mas impóe ao Estado um dever de agir de forma justa em todas as suas ações que possam atingir a vida, a liberdade e a propriedade dos indivíduos.

Além disso, restou claro que o conceito de vida, liberdade e propriedade ganharam definições mais amplas, passando a proteger a privacidade, a igualdade, dentre outros direitos correlatos ao exercício daqueles inscritos expressamente no princípio. Assim, segundo DAURA (2009, p. 32-33):

énecessário frisar que a garantia da Constituição quando menciona o princípio do devido processo legal não o relaciona somente com as esferas processuais penal ou civil mas com 'tudo o que disser respeito à tutela da vida, liberdade e propriedade, como por exemplo, o direito á integridade moral, a liberdade religiosa e de manifestação 
do pensamento' (NERY JÚNIOR, 1997, p. 36). O due process of law, enquanto principio, apresenta um sentido mais amplo, que se carateriza pelo trinômio vida-liberdade-propriedade.

Em concomitância à evolução das teorias constitucionalistas, umbilicamente ligada à proteção e efetivação dos direitos fundamentais do homem, o direito penal seguiu na mesma direção, exigindo que o homem - o ser humano - seja o centro e a razão de existência de todo o sistema punitivo. Decorre daí uma concepção equilibrada do Direito penal, onde se encontra, de um lado: 1) a proteção de bens jurídicos da sociedade, importando na própria manutenção do Estado Democrático de Direito, e de outro: 2) os direitos humanos do próprio delinquente contra os excessos do Estado.

Assim, desde que o Estado tomou para si o monopólio da justiça penal, por meio da qual é o único autorizado a impor consequencias jurídicas que restrinjam os direitos fundamentais dos indivíduos, mormente a liberdade, deve ser compreendido que todo o processo, desde o seu nascedouro, incluindo a investigação criminal, deve se pautar por princípios e normas legais que configurem um agir justo. Nos dizeres de Valente (2010, p. 47):

$O$ direito penal humanista impóe ao Estado (ao soberano) a existência de garantias processuais como a obtenção de provas com respeito pela liberdade plena do cidadão (liberdade de decisão e acção), com respeito à ordem jurídica legitimada por cada pessoa da coletividade. Do mesmo modo impóe ao Estado que não aplique a jujstiça como o indivíduo aplicaria por meio da vingança, que garanta, ao cidadão, a defesa do que é acusado ou indiciado e que seja, em efetivo, reconbecido ao cidadão o direito de presunção de inocência até o trânsito em julgado.

É certo que a investigação criminal é a base de todo o sistema processual penal, tanto para o ajuizamento da ação penal, mas principalmente para o desenvolvimento do processo penal em juízo, pois ao reconstruir o fato criminoso, coleta evidências e vestígios e produz provas que serão impossíveis de serem exatamente repetidas posteriormente, seja pelo decorrer do tempo, quando se observa o princípio da oportunidade, seja por absoluta impossibilidade fática.

Ainda que o objetivo imediato da investigação criminal não seja a punição de quem quer que seja, como afirmado alhures, pois a investigação criminal se destina à apuração de um fato criminoso, produzindo uma verdade 
processual, também é inegável que ela, por si só, poderá impor restrições aos direitos fundamentais do investigado.

A instauração de procedimento formal legal de investigação pode causar limitações aos direitos fundamentais do homem, sejam eles de menor repercussão, como danos à imagem ou honra dos envolvidos (alguns irreparáveis), ou mesmo conduzir à restrição de sua liberdade (prisões cautelares) ou propriedade (apreensóes, sequestros). Além disso, a certeza de que o procedimento seguirá a sua marcha e em última instância poderá servir de base a eventual ajuizamento de ação penal ou mesmo de uma condenação criminal é suficiente para compreender que o investigado não é um mero objeto à disposição do Estado. Não há espaço, em qualquer momento da persecução criminal para considerar o indivíduo desprovido de direitos fundamentais.

Portanto, a toda evidência, o princípio do devido processo legal deve ser plenamente respeitado durante a investigação criminal, desde o seu início, incluindo o seu desenvolvimento e até mesmo após o seu término.

Como já dito, a investigação criminal cuida especialmente da reconstrução de fatos, em proximidade com as investigações científicas e a busca pela verdade, tendo limitações de ordem jurídica, tanto no que tange ao direcionamento da apuração, mas também no seu alcance e limites. Neste particular, o devido processo legal se caracteriza como sendo o balizamento jurídico, o limite negativo, por meio do qual a investigação criminal deve se ater para que não ofenda direitos fundamentais do homem de maneira proibida.

E como o objeto da investigação criminal é o fato criminoso, forçoso reconhecer que as permissões ou proibições jurídicas para elucidálo influenciam na caracterização da verdade. Este é o desafio que envolve os temas relativos à prova, pois concomitantemente, dizem respeito a procedimento e conteúdo, à forma e substância. Os estudiosos do due process of law nos Estados Unidos perceberam a dificuldade de distinção entre as suas dimensões do devido processo quando se trata da justiça criminal e da verdade probatória:

Afirmam os docentes que, no tocante à prova, por exemplo, as questôes procedimentais (procedural) misturam-se com as questões substancias (substantive). Uma coisa éser faticamente culpado e outra, legalmente 
culpado, asseguram. E as regras são estabelecidas com a Justiça em mentepara os dois pontos de vista. Toda norma atinente à prova afeta $o$ resultado do processo e, nesse aspecto, tem força substancial. Mas virtualmente toda norma de prova também é sobre procedimento e assim, procedimental. (PEREIRA, 2008, p. 92)

Assim, na hipótese supracitada, as violações de cunho procedimental podem invalidar evidências ou provas que elucidam o fato criminoso, ou seja, tais proibições de procedimento influenciam o conteúdo da investigação, mesmo quando dizem respeito apenas à forma como foram obtidas. Uma confissão produzida em razão da prática de tortura seria o clássico exemplo de que a forma proibida por lei para a colheita da prova invalida as informações obtidas pelo ato, ainda que elas possam revelar ou elucidar materialmente o fato investigado.

Também se incluem nesta hipótese os atos investigativos realizados no bojo de instrumentos ilegais de investigação criminal. $\mathrm{O}$ manejo de procedimento de investigação criminal, base inicial para a imposição de conseqüências criminais que possam afetar diretamente a vida, a liberdade e a propriedade do indivíduo, deverá se ater, no mínimo, às exatas prescrições legais de procedimento e forma.

Não se concebe a existência de um procedimento de investigação criminal ou com finalidade criminal, realizada à sorrelfa do direito e da lei. No caso, tais instrumentos de investigação não podem embasar, sem ofensa ao devido processo legal, ação penal cujo propósito final é a condenação do indivíduo a penas que poderão lhe restringir a vida, liberdade ou propriedade. A investigação criminal não cuida apenas de obter informações sobre um fato, mas trata-se de desvendar um crime, remetendo-se a todas as consequencias que envolvem o conceito de ilícito penal.

$\mathrm{Na}$ consecução do direito processual penal não há espaço para subterfúgios, pois as possíveis consequencias poderão ofender aos bens mais preciosos do ser humano, mormente a liberdade. Ora, quaisquer procedimentos, distintos daqueles previstos pela Lei, cuja finalidade precípua não envolve a apuração de delitos, não podem ser usados em processo criminal, uma vez que afrontam o devido processo legal, bem como ao princípio da legalidade. $\mathrm{O}$ devido processo legal impõe ao Estado a necessidade do agir justo. Assim o Estado não pode patrocinar procedimentos inexistentes juridicamente, ou cuja aparência se presta apenas para esconder outras intenções.

Recentemente, a República Federativa do Brasil foi condenada pela Corte Interamericana de Direitos Humanos pela promoção de atos de in- 
vestigação conduzidos em procedimentos irregulares. No caso, pela falta de instrumento formal de investigação a dar supedâneo a medidas cautelares, conforme trecho abaixo transcrito do caso Escher e Outros v. Brasil, julgado em julho de 2009:

De acordo com o artigo $1^{\circ}$ da Lei n. 9.296/96, a interceptação telefônica deve ter o propósito de investigar criminalmente ou de instruir um processo penal. No presente caso, apesar de indicar a necessidade de investigar supostas práticas delitivas, quais sejam, $o$ homicídio de Eduardo Aghinoni e o desvio de recursos públicos, a solicitação do major Neves não foi apresentada no marco de um procedimento investigativo que tivesse por objeto a verificação dos fatos. $O$ pedido de interceptação sequer mencionou os autos da investigação do homicídio que se encontrava a cargo da polícia civil de Querência do Norte, cujo delegado de polícia não teria sido notificado a respeito. Outrossim, tampouco consta que na época dos fatos existisse uma investigação pelo suposto desvio de recursos públicos por parte dos dirigentes da COANA e da ADECON. Quanto ao pedido do sargento Silva, este não apontou o propósito das interceptações pretendidas nem sua vinculação com uma investigação ou processo penal. Desse modo, em detrimento do artigo $8^{\circ}$ da Lei No. 9.296/96, o Pedido de Censura foi uma diligência isolada e não tramitou em autos anexos a um procedimento de investigação ou processo criminal iniciados anteriormente. Portanto, ambas as solicitações descumpriram com $o$ disposto nos artigos supracitados. (grifos nossos) $)^{5}$

E conclui:

A Corte conclui que as interceptaçôes e gravações das conversas telefônicas objeto deste caso não observaram os artigos $1^{\circ}, 2^{\circ}, 3^{\circ}, 4^{\circ}, 5^{\circ}$, $6^{\circ}$ e $8^{\circ}$ da Lei No. 9.296/96 e, por isso, não estavam fundadas em lei. Em consequência, ao descumprir o requisito de legalidade, não resulta necessário continuar com a análise quanto à finalidade e à necessidade da interceptação. (grifo nosso) ${ }^{6}$

De modo geral, a grande maioria dos limites impostos pelo devido processo legal à investigação criminal residem nesta região obscura onde procedimento formal e conteúdo se confundem.

5 Cf. Disponível em: http://www.corteidh.or.cr/docs/casos/articulos/seriec_200_por.pdf. Acesso em: 01 nov. 2010, p. 41

6 Cf. Disponível em: http://www.corteidh.or.cr/docs/casos/articulos/seriec_200_por.pdf. Acesso em: 01 nov. 2010, p. 45. 
Contudo, existem regras exclusivamente procedimentais, que não exercem influência sobre o conteúdo da prova, e que embora exijam o seguimento estrito de determinado rito ou forma, o conteúdo da investigação não será afetado caso tal prescrição não seja respeitada. Tais infraçôes procedimentais podem acarretar prejuízos ao desenvolvimento do processo penal ou da própria investigação, mas o conteúdo da apuração, a elucidação do fato criminoso não é prejudicado. Cite-se, por exemplo, o relaxamento da prisão em flagrante delito pela falta de comunicação ao juízo competente da medida cautelar aplicada. Assim, embora a prisão cautelar reste prejudicada e eventualmente cause algum prejuízo ao regular desenvolvimento do processo penal ou da investigação, as provas colhidas durante a lavratura da peça procedimental permanecem perfeitas e plenamente válidas.

E por fim, poder-se-ia cogitar atos que mesmo atendendo aos ditames procedimentais ofenderiam a limites materiais implicitamente inscritos pelo devido processo legal substantivo, intimamente relacionados à razoabilidade e proporcionalidade.

Vislumbra-se, no caso, a imposição de prisões ou medidas cautelares a hipóteses previstas pela legislação, mas que quando comparadas às conseqüências materiais do ato, especialmente as restriçôes que imporá à vida, liberdade, ou propriedade do indivíduo, não se justificam considerando as suas finalidades na elucidação do fato.

Cabe citar também a participação abusiva de uma das partes do processo penal durante a investigação criminal. No caso, ainda que procedimentalmente a investigação criminal esteja plenamente perfeita, substancialmente ou materialmente o seu conteúdo poderá estar impregnado pela visão distorcida de uma das partes, antes mesmo do processo penal. Assim como o Ministério Público, titular da ação penal, não poderia exceder na utilização de seus poderes antes da propositura do processo penal, sob pena de tornar desleal a instrução criminal previamente viciada, a defesa do indivíduo também não está autorizada a impedir, sem o manejo de instrumentos legalmente permitidos, o desenvolvimento normal de uma legítima investigação criminal, emboralhe seja constitucionalmente garantida, sem outros prejuízos, a posição de total inércia perante o Estado. Tudo isso porque o devido processo legal determina a observância da paridade de armas no desenvolver do procedimento, corolário do princípio do contraditório. 
Resumem-se, portanto, as três hipóteses acima aventadas: 1) atos ou medidas investigativas que ofendam normas procedimentais, mas que implicam restrições ao conteúdo da investigação criminal; 2) atos ou medidas que infringem normas exclusivamente procedimentais e que não afetam o conteúdo da investigação e, por fim; 3) atos ou medidas que transgridem disposições jurídicas de cunho substancial, referentes exclusivamente ao conteúdo da investigação. $\mathrm{Na}$ primeira e terceira hipóteses teríamos a ocorrência de vícios insanáveis, podendo resultar na completa nulidade da investigação criminal. Já na segunda hipótese, os atos poderiam ser repetidos, ou mesmo desconsiderados, sem qualquer prejuízo à investigação criminal.

\section{Conclusões}

O conceito do princípio do devido processo legal sofreu intensa e constante evolução nos países que já o consagraram em seus sistemas jurídicos. Seu sentido tornou-se mais abrangente, abrigando um padrão de justiça a ser seguido pelo Estado quando em risco a vida, a liberdade e a propriedade dos indivíduos.

O devido processo legal deixa de ser mera garantia do direito processual penal, e passa a ser aplicado também ao direito processual civil, ao direito administrativo e por fim, para verificar a razoabilidade do conteúdo das leis perante o sistema jurídico vigente. No caso, sempre que houver a possibilidade do Estado invadir indevidamente a vida, a liberdade e a propriedade dos indivíduos o princípio do devido processo legal poderá ser invocado.

Por outro lado, se analisou a investigação criminal, tendo como foco, o seu contéudo e a forma como é expressa. Considerando o seu conteúdo, se verifica que a busca pela verdade na elucidação do fato criminoso encontra limites e direcionamento pela ordem jurídica. Já no que tange à sua forma, o procedimento através do qual a investigação se manifesta deve ser previsto expressamente em dispositivo legal, conforme listados nas seções anteriores. Vislumbra-se, portanto, a evidente interferência da ciência do direito na apuração da verdade fática, tanto a verificada no seu conteúdo quanto à sua forma.

E considerando as evidentes consequências jurídicas advindas da investigação criminal, tanto diretamente quanto indiretamente, à vida, à liberdade e propriedade do indivíduo, torna-se óbvia a necessidade de 
observância do devido processo legal pelo Estado durante a realização da investigação criminal.

No caso, os limites e condicionamentos jurídicos impostos à investigação criminal correspondem ao limites exigidos pelo princípio do devido processo legal para que o Estado possa, de forma legítima e legal de investir sobre a vida, liberdade e propriedade dos indivíduos.

E considerando que o tema primordial da investigação criminal envolve o conceito de prova, as limitações de ordem procedimental influenciam também no conteúdo da apuração. E o que ocorre na produção de provas ilícitas ou de investigações criminais conduzidas em procedimentos ilegais. E embora existam proibições de cunho estritamente procedimentais que não influenciam no conteúdo da investigação, vislumbra-se também a existência de proibições referentes exclusivamente ao conteúdo, que não ofendem a regras de procedimento, mas que se configuram em hipóteses vedadas, como aplicação de medidas cautelares desproporcionais ou que ofendam a paridade de armas.

DANIEL FÁBIO FANTINI

\footnotetext{
O autor é Delegado de Polícia Federal, Chefe Substituto da Delegacia de Polícia Federal em Divinópolis/MG, bacharel em Direito pela Universidade Federal de Minas Gerais - UFMG E Aluno do CURSo de EsPeCIAlizaÇão EM CiêNCIA Policial E INVESTIGAÇão CRIMINAL - 2010/2011 OFERECIDo PELA ANP/DPF. No Departamento de Polícia Federal já ocupou as Chefias da Delegacia de Repressão ao Tráfico de Armas, de IMigraÇÃo E DE Defesa Institucional.
}

\title{
DUE PROCESS OF LAW AND CRIMINAL INVESTIGATION
}

\begin{abstract}
This paper discusses the evolution of the due process of law principle, in its two dimensions procedural and substantive, until its express enactment in the 1988 Constitution of the Federal Republic of Brazil. Accordingly, it clearly sets forth that the due process of law clause constitutes a bulwark of justice, directed toward protecting the fundamental rights and guarantees of individuals, above all, those of life, liberty and property, against any and every unreasonable action the state might effect. In turn, it broaches the matter of the criminal investigation as a process the state has at its disposal for the elucidation of criminal facts, clarifying the relation between factual
\end{abstract}


truth and the constraints of the legal system to which it is subject. In this light, it considers that the content and methods of criminal investigations are influenced by legal guidelines, although the acts destined to elucidate the criminal fact verge on scientific investigations. Hence, bearing in mind that a criminal investigation could limit, directly or indirectly, the rights of the individual to life, liberty and property, the application of the principle of due process is justified in relation to acts effected within the sphere of an instated investigative process purporting inquiry into a felony committed. Finally, it identifies that the legal limits imposed on a criminal investigation translate into the effective application of due process, whether in relation to aspects inherent to the content or to the formal procedures of the investigation.

KEYwORDS: Due process of law. Dimensions of Due process of Law. Criminal Investigations. Content and Procedures. Criminal Investigations Legal Restrictions.

\section{REFERÊNCIAS}

BARACHO, José Alfredo. "Processo e Constituição: o devido processo legal”. Belo Horizonte: Movimento Editorial da Revista da Faculdade de Direito da UFMG, 1982, p.59-103.

CANOTILHO, José Joaquim Gomes. Direito Constitucional e Teoria da Constituição. 2. ed. Coimbra: Livraria Almedina, 1998.

CASTRO, Carlos Roberto de Siqueira. O devido processo legal e a razoabilidade das leis na nova constituição do Brasil. Rio de Janeiro: Forense, 1989.

DAURA, Anderson Souza. Inquérito Policial: competência e nulidade dos atos de polícia judiciária. 3. ed. rev. e atual. Curitiba: Juruá, 2009.

DUTRA, Luiz Henrique de Araújo. Pragmática da Investigação: modelos intencionais na investigação policial. Revista Brasileira de Ciências Policiais. v. 1, n. 1, jan-jun/2010, 137-152.

FERRAJOLI, Luigi. Direito e Razão: Teoria do garantismo penal. São Paulo: RT, 2002.

FOUCAULT, Michel. A verdade e as formas jurídicas. 2. ed. Rio de Janeiro: Departamento de Letras PUC, 2001.

LUCON, Paulo Henrique dos Santos. Devido processo legal substancial. Palestra - IV Jornadas Brasileiras de Direito Processual Civil, 2001. Disponível em: <http://www.cursomarcato.com.br/admin/ mod_ac/doutrinas/009.doc>. Acesso em: 29 set. 2010. 
MACIEL, Adhemar Ferreira. Devido processo legal e a Constituição Brasileira de 1988: doutrina e jurisprudência: direito comparado. BDJur, Brasília, DF, 21 jul. 2009. Disponível em: <http://bdjur.stj. gov.br/dspace/handle/2011/23065>. Acesso em 21 set. 2010.

PEREIRA, Eliomar da Silva. Investigação criminal: uma abordagem jurídico-científica. Revista Brasileira de Ciências Policiais. v. 1, n. 1, jan-jun/2010, 213-242.

PEREIRA, Sebastião Tavares. Devido Processo Substantivo. Florianópolis: Conceito Editorial, 2008.

SILVEIRA, Paulo Fernando. Devido Processo Legal. 3. ed. Belo Horizonte: Del Rey, 2001.

VALENTE, Manuel Monteiro Guedes. Teoria geral do direito policial. 2. ed. Coimbra: Almedina, 2009.

VALENTE, Manuel Monteiro Guedes. Direito penal do inimigo e o terrorismo: $\mathrm{o}<$ progresso ao retrocesso $>$. Coimbra: Almedina, 2010.

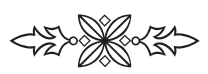

